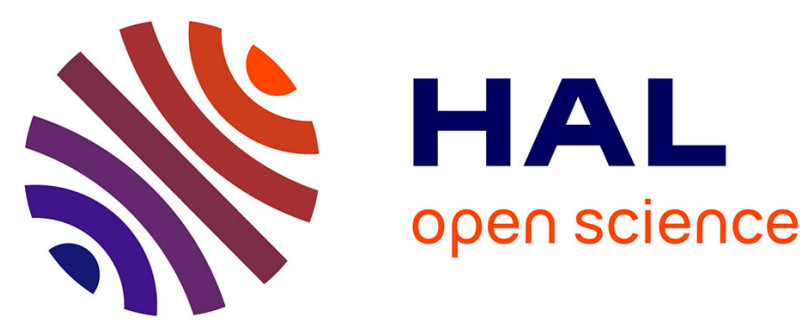

\title{
Response to Letter to the Editor regarding "Development of an antibody-free ID-LC MS method for the quantification of procalcitonin in human serum at sub-microgram per liter level using a peptide-based calibration"
}

Huu-Hien Huynh, Amandine Bœuf, Maxence Derbez-Morin, Anne-Marie

Dupuy, Béatrice Lalere, Joëlle Vinh, Vincent Delatour

\section{- To cite this version:}

Huu-Hien Huynh, Amandine Bœuf, Maxence Derbez-Morin, Anne-Marie Dupuy, Béatrice Lalere, et al.. Response to Letter to the Editor regarding "Development of an antibody-free ID-LC MS method for the quantification of procalcitonin in human serum at sub-microgram per liter level using a peptide-based calibration". Analytical and Bioanalytical Chemistry, 2021, 413 (19), pp.4921-4922. 10.1007/s00216-021-03465-7 . hal-03335235

\author{
HAL Id: hal-03335235 \\ https://hal.science/hal-03335235
}

Submitted on 7 Oct 2021

HAL is a multi-disciplinary open access archive for the deposit and dissemination of scientific research documents, whether they are published or not. The documents may come from teaching and research institutions in France or abroad, or from public or private research centers.
L'archive ouverte pluridisciplinaire HAL, est destinée au dépôt et à la diffusion de documents scientifiques de niveau recherche, publiés ou non, émanant des établissements d'enseignement et de recherche français ou étrangers, des laboratoires publics ou privés. 


\title{
Response to Letter to the Editor regarding "Development of an antibody-free ID-LC MS method for the quantification of procalcitonin in human serum at sub-microgram per liter level using a peptide-based calibration"
}

\author{
Huu-Hien Huynh ${ }^{1,2} \cdot$ Amandine Bœuf $^{1}$ (10) Maxence Derbez-Morin ${ }^{1,3} \cdot$ Anne-Marie Dupuy $^{4} \cdot$ Béatrice Lalere $^{1}$. \\ Joëlle Vinh ${ }^{2} \cdot$ Vincent Delatour $^{1}$
}

Received: 2 June 2021 / Accepted: 8 June 2021 / Published online: 2 July 2021

(C) Springer-Verlag GmbH Germany, part of Springer Nature 2021

Dear Editor,

In this issue, Tölke et al. responded to our recently published paper describing an antibody-free method for procalcitonin (PCT) quantification by isotope-dilution coupled to liquid chromatography and tandem mass spectrometry (ID-LC-MS/MS) [1]. This group proposes a MS-based quantification strategy that relies on polyclonal antibodybased enrichment for PCT affinity purification at the protein level [yet unpublished].

We agree with Tölke et al. that immunoaffinity has several advantages, especially a less laborious sample preparation step than our two-step solid-phase extraction (SPE) at protein and peptide levels. Although SPE is presumably a less specific sample preparation procedure, we believe that this turns into an advantage in the sense that our antibody-free method is more prone to quantify the total PCT content, particularly if PCT is bound to other proteins or if the different forms of PCT are not recognized by the antibody with the same affinity. Additionally, we believe that antibody-based capture of

This article is a response to the 'Letter to the Editor' to be found at DOI https://doi.org/10.1007/s00216-021-03459-5

Amandine Bœuf

amandine.boeuf@lne.fr

1 Biomedical and Organic Chemistry Department, Laboratoire National de Métrologie et d'Essais (LNE), Paris, France

2 Biological Mass Spectrometry and Proteomics, SMBP, ESPCI Paris, Université PSL, CNRS FRE2032, Paris, France

3 Université Paris-Saclay, CEA, INRAE, Département Médicaments et Technologies pour la Santé (DMTS), SPI, Gif-sur-Yvette, France

4 Laboratoire de Biochimie et Hormonologie, CHU Montpellier, Université Montpellier 1, Montpellier, France
PCT, mainly when using polyclonal antibodies, can be subject to a higher risk of batch-to-batch variations in specificity that could compromise the method's intermediate precision over a prolonged time [2, 3]. Moreover, polyclonal antibodies can be subject to cross-reactivity issues that could result in the extraction of other proteins than PCT. Although the method's specificity is probably not affected thanks to the MS-based detection, this could potentially reduce the method's sensitivity. Even if studies are currently addressing this limitation [4], our work aimed to avoid this effect by developing an antibody-free procedure.

Another significant difference is that Tölke's method relies on protein-based calibrators while ours involves peptidebased calibrators. As described in our paper, we agree that protein-based calibration relying on a non-labelled recombinant protein as primary calibrator and a labelled recombinant protein as internal standard is preferable because the internal standard is added from the start of the sample preparation procedure, thereby compensating variability and material losses occurring during the whole procedure. Also, a protein-based primary calibrator has the advantage of behaving the closest to endogenous PCT, and no bias between calibrators and patient samples can be introduced during sample preparation (protein extraction, protein digestion). However, the actual concentration of a recombinant protein purchased from commercial sources varies greatly depending on its purity and quantitative methods (e.g., bicinchoninic acid assay, amino acid analysis). To ensure the result's accuracy and traceability to the SI units, the purity assessment and characterization of the primary calibrator are crucial. Still, it is more challenging for proteins than for peptides due to the size, the number, and the complexity of the process-related impurities (mainly proteins) generated during the production of the protein of interest [5]. Indeed, the current state of the art 
recommends using a primary reference method correcting the contribution of structure-related impurities (e.g., PICAA, corrected qNMR) [6]. To make this as straightforward as possible, it is therefore very beneficial to optimize the protein purification protocol (e.g., by combining size exclusion, ion exchange, reverse-phase chromatography) to reduce the number of impurities to be quantified. To overcome the limitations of our published method, we recently developed an absolute quantification method by ID-LC-MS/MS that relies on a protein-based calibration with an SI-traceable, well-characterized, highly purified recombinant protein.

Although it could be expected that immunoaffinity would allow improving the method's sensitivity, both methods have almost the same limit of quantification (LOQ) $(0.25 \mu \mathrm{g} / \mathrm{L}$ for our antibody-free method and $0.5 \mu \mathrm{g} / \mathrm{L}$ for Tölke's method). Both are based on detecting a single tryptic peptide (LLLAALVQDYVQMK in Tölke's method, SALESSPADPATLSEDEAR in our method). Bearing in mind that these IDMS methods were developed to become secondary reference measurement procedures, a LOQ of $0.25 \mu \mathrm{g} / \mathrm{L}$ is sufficient to assign target values to quality control materials that could be used to monitor accuracy and comparability of routine assays but not to assign target values to calibration materials because most immunoassays have a lower LOQ.

Given that the two methods rely on two different sample preparation approaches, it will be of great interest to organize a round-robin study to compare the results provided by the two methods. This will pave the road to establish a network of calibration laboratories operating reference methods for PCT, as planned within IFCC WG-PCT [7].

Funding This work was supported by the European Metrology Programme for Innovation and Research (EMPIR) joint research projects [15HLT07] "AntiMicroResist" and [18HLT03] "SEPTIMET" which have received funding from the EMPIR programme co-financed by the Participating States and the European Union's Horizon 2020 research and innovation programme. Huu-Hien Huynh and Maxence Derbez-Morin were supported by a CIFRE scholarship provided by ANRT (Association Nationale de la Recherche et de la Technologie). Conseil Régional d'Île-de-France subsidized SMBP mass spectrometry equipment (Sesame 2010 No. 10022268).

\section{Declarations}

Conflict of interest The authors declare no competing interests.

\section{References:}

1. Huynh HH, Bœuf A, Derbez-Morin M, Dupuy AM, Lalere B, Delatour V, et al. Development of an antibody free ID-LC MS method for the quantification of procalcitonin in human serum at submicrogram per liter level using a peptide-based calibration. Anal Bioanal Chem. 2021. https://doi.org/10.1007/s00216-021-03361-0.

2. Bradbury A, Pluckthun A. Reproducibility: standardize antibodies used in research. Nature. 2015;518:27-9.

3. Popow I, Leitner J, Otto M, Johannes JK, Saemann MD, Zlabinger GJ, et al. Assessment of batch to batch variation in polyclonal antithymocyte globulin preparations. Transplantation. 2012;93:3240.

4. Keating SM, Mizrahi RA, Adams MS, Asensio MA, Benzie E, Carter KP, et al. Generation of recombinant hyperimmune globulins from diverse B-cell repertoires. Nat Biotechnol. 2021. https://doi. org/10.1038/s41587-021-00894-8.

5. Wang W, Ignatius AA, Thakkar SV. Impact of residual impurities and contaminants on protein stability. J Pharm Sci. 2014;103:131530 .

6. Josephs RD, Martos G, Li M, Wu L, Melanson JE, Quaglia M, et al. Establishing of measurement traceability for peptide and protein quantification through rigorous purity assessment-a review. Metrologia. 2019;45:044006.

7. Huynh HH, Boeuf A, Vinh J, Delatour V. Evaluation of the necessity and the feasibility of the standardization of procalcitonin measurements: activities of IFCC WG-PCT with involvement of all stakeholders. Clin Chem Acta. 2021;515:111-21.

Publisher's note Springer Nature remains neutral with regard to jurisdictional claims in published maps and institutional affiliations. 